\title{
Impact of earthquake-induced-landslides on hydrologic response of a steep mountainous catchment: a case study of the Wenchuan earthquake zone"
}

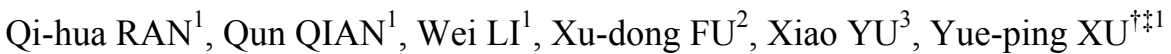 \\ ( ${ }^{1}$ Institute of Hydrology and Water Resources, Zhejiang University, Hangzhou 310027, China) \\ ( ${ }^{2}$ State Key Laboratory of Hydroscience and Engineering, Tsinghua University, Beijing 100084, China) \\ ( ${ }^{3}$ China Three Gorges Corporation, Beijing 100038, China) \\ ${ }^{\dagger}$ E-mail: yuepingxu@zju.edu.cn
}

Received Jan. 25, 2014; Revision accepted Apr. 17, 2014; Crosschecked Jan. 12, 2015

\begin{abstract}
Earthquake-induced-landslides will change the underlying surface conditions (topography, vegetation cover rate, etc.), which consequently may influence the hydrologic response and then change the flash flood risk. The Jianpinggou catchment, located in the Wenchuan earthquake (occurred in Sichuan, China, 2008) affected area, is selected as the study area. The distribution of the landslides is obtained from the remote sensing image data. The changes of topography are obtained from the comparisons among digital elevation models (DEMs) during different periods. A physical-based model, the integrated hydrology model (InHM), is used to simulate the hydrologic response before and after the landslide. The influence of the underlying surface conditions is then discussed based on the simulation results. The results reveal that landslides cause significant effects on the hydrologic response, and the impact is proportional to the proportion of surface flow in the total runoff. The effect of landslides on the runoff is insignificant at the outlet, but obvious in the local area. The larger the rainfall, the more visible the impact, and the impact of landslides will increase rapidly at the threshold of the runoff (the total rainfall of $235 \mathrm{~mm}$ in $6 \mathrm{~h}$ in the study area), but there is a limit with the further enlarged rainfall. The improved understanding of the impact of landslides on the hydrologic response provides valuable theoretical support for storm flood forecasting.
\end{abstract}

Key words: Underlying surface conditions, Landslide, Earthquake, Hydrologic response, Numerical simulation doi: 10.1631 jzus.A1400039

Document code: A

CLC number: TV121

\section{Introduction}

The Wenchuan earthquake with a magnitude of 8.0 on the Richter scale, in Sichuan, China, on May 12,2008 , had caused a large number of landslides besides enormous casualties and economic losses. The occurrence of earthquake-induced-landslides is

\footnotetext{
Corresponding author

* Project supported by the National Basic Research Program (973 Program) of China (No. 2011CB409901-01), and the Zhejiang Provincial Natural Science Foundation of China (No. R5110012) (D) ORCID: Qi-hua RAN, http://orcid.org/0000-0003-3555-2596; Yueping XU, http://orcid.org/0000-0002-3259-5593

(C) Zhejiang University and Springer-Verlag Berlin Heidelberg 2015
}

up to 40000-50000, and more than 30 landslides have a size of more than 10 million $\mathrm{m}^{3}$ (Cui et al., 2011).

The effect of these landslides cannot be overlooked in the earthquake affected areas. The landslides usually lead to a variation of the runoff and debris flow (Liu et al., 2006; Hong et al., 2010; Chen, 2011). In terms of the hydrological response, the impact of the landslides is mainly reflected in the changes of the underlying surface conditions, such as the micro-topography and vegetation cover rate.

The changes in the micro-topography caused by the landslides are significant, such as the exposed bedrock in the trailing edge of the landslide, the steep 
slope, and the accumulations of loose materials in the lower part of the landslide. The loose solid materials are easy to enter and clog, or even completely block off the channel and river (Xu et al., 2010). Specifically, the exposed bedrock surfaces, which were formed by the landslides, usually have the steep slope and smooth surface. Thus, the infiltration of surface water is reduced, leading to faster runoff generation and convergence processes, and usually resulting in higher flow velocity. In the area of soil accumulation, the loose soil structure and large porosity could lead to the high infiltration rate, and the rapid infiltration would occur in the heavy rainfall conditions (Cui et al., 2010). On the other hand, the path of the overland flow is also influenced by the changes of the slope and depression distributions caused by the landslides (Dunne et al., 1991; Liu and Singh, 2004). The characteristics of the landslide area indicated the influence of the landslide on the rainfall-runoff process.

The changes of vegetation cover rate caused by the landslides are reflected in the formation of vast exposed soil areas and the destruction of vegetation, thereby causing the hydrodynamic and hydrological changes. The surface soil saturation conductivity is also changed by the exposed soil and bedrock, thereby affecting the runoff generation and convergence characteristics. These changes may affect the runoff sources, leading to different runoff composition (such as increasing the surface flow and decreasing the subsurface flow) (Zheng et al., 2010).

Over the past decades, the impact of the underlying surface conditions on the runoff formation has been documented, mainly focusing on the influence of vegetation changes (Shi and Chen, 2004; Bari et al., 2005), urbanization (Campana and Tucol, 2001), as well as the resolution of terrain data used in the models (Sulis et al., 2011). However, the impact of the underlying surface conditions induced by the landslides on the hydrologic response at the catchment scale is not yet clear.

In this study, a small catchment located in the Wenchuan earthquake affected area, the Jianpinggou catchment, is selected as the study site. The remote sensing image and digital elevation model (DEM) data are used for obtaining the changes of the underlying surface conditions that were caused by the landslides. Due to the lack of hydrological measurements in this catchment before the earthquake, a physical-based model, the integrated hydrology model (InHM), is used to simulate the hydrologic response before and after the landslide occurrence. The influences of the underlying surface conditions on the hydrologic response in the Jianpinggou catchment are then discussed based on the output data, such as the hydrograph, distributed water depths, and local runoffs.

\section{Study area}

The Jianpinggou catchment is located at the Minjiang River, a tributary of the upper Yangtze River, watershed, and has an area of about $3.5 \mathrm{~km}^{2}$. The elevation in the Jianpinggou catchment ranges from $1050 \mathrm{~m}$ to $2199 \mathrm{~m}$. The main channel length is $1.7 \mathrm{~km}$. The average slope is $31.7 \%$, and the average longitudinal gradient of the flow is $36.3 \%$. Based on the field surveys across the catchment, the soil profile has two horizons as well as the underlying bedrock. The first horizon is soil, and is about $0.5 \mathrm{~m}$ thick mainly with silty clay and silt loam. The second horizon is about $2.5 \mathrm{~m}$ thick with a high content of bedrock fragments. The underlying bedrock is comprised of the basalt, tuff, and andesite rocks (Chu et al., 2011). The vegetation cover rate of the catchment is high. The climate is subtropical and humid. The average annual rainfall is $800-900 \mathrm{~mm}$, and about $80 \%$ of this occurs in the rainy season (from May to September). The hydrologic response is dominated by the Dunne overland flow and subsurface flow (Qian and Ran, 2012). Rare landslide disasters have occurred before the Wenchuan earthquake in 2008, but a large number of landslide hazards have been induced during and after the earthquake. Fig. 1 shows the remote sensing image of the Jianpinggou catchment before (in 2005) and after (in 2011) the earthquake.



(a)

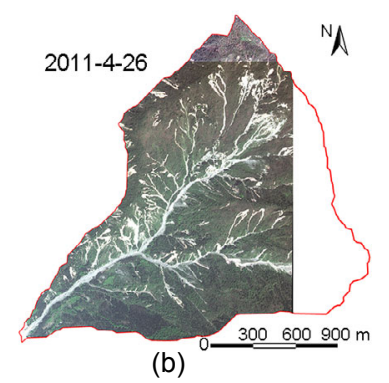

(b)
Fig. 1 Remote sensing image of Jianpinggou catchment before (a) and after (b) the earthquake 


\section{Data and methods}

\subsection{Data}

A water stage gauge and three rain gauges were installed in the area (Fig. 2a) for hydrological data collection since 2011. The gauges were located in the downstream area as it is hard to install in the upstream area due to the lush vegetation and steep hill slopes. Unfortunately, a flood event in July 2011 destroyed the instrument, resulting in a serious lack of data. Rainfall data was available only from August to October 2011, and water stage data was available from September 2011 to January 2012. The manning's equation with measured hydraulic factors was performed to evaluate the stage and discharge. So the study period was chosen from 16th September to 14th October, 2011. Note that this period is at the end of the wet season, and there are no flood events in this period. Therefore, the observed hydrograph is just a part of one event.

\subsection{InHM}

The InHM is used in this study. InHM was originally designed by VanderKwaak (1999), and then modified by the hydrogeology group at Stanford University (Loague et al., 2005; Heppner et al., 2006; Ran et al., 2007). The model can simulate the surface and subsurface hydrologic responses, a great deal of the distributed response data (e.g., surface saturation, discharge) can be outputted, and there is no a priori assumption of a specific runoff-generation mechanism (e.g., Horton or Dunne overland flow). InHM had been successfully applied in hydrologic-response simulations of a catchment/watershed scale (VanderKwaak and Loague, 2001; Loague and VanderKwaak, 2002; Loague et al., 2005; Ebel et al., 2008; Mirus et al., 2009; 2011; Mirus and Loague, 2013), sediment transport (Heppner and Loague, 2008; Ran et al., 2012; 2013), and slope failure (BeVille et al., 2010; Ebel et al., 2010). The two governing equations of the surface and subsurface flow components of InHM are presented in the following paragraphs, and the complete description of InHM is referred to (VanderKwaak, 1999; Heppner et al., 2006).

The transient flow on the surface (both overland and open channel) is estimated by the diffusion wave approximation of the depth-integrated shallow water equations. Such 2D surface flow is conceptualized as a second continuum, which interacts with the underlying variably saturated porous medium through a thin soil layer of thickness $\alpha_{\mathrm{s}}$ [L]. Assuming a shallow depth of water, $\psi_{\mathrm{s}}[\mathrm{L}]$, and the negligible influence of inertial forces, the conservation of water on the land surface is described by

$$
\nabla \cdot \psi_{\mathrm{s}}^{\text {mobile }} \boldsymbol{q}_{\mathrm{s}} \pm \alpha_{\mathrm{s}} q^{\mathrm{b}} \pm \alpha_{\mathrm{s}} q_{\mathrm{sp}}^{\mathrm{e}}=\frac{\partial\left(S_{\mathrm{w}_{\mathrm{s}}} h_{\mathrm{s}}+\psi_{\mathrm{s}}^{\text {store }}\right)}{\partial t}
$$

where $\boldsymbol{q}_{\mathrm{s}}$ is the surface water velocity $\left[\mathrm{LT}^{-1}\right] ; q^{\mathrm{b}}$ is a specified rate source/sink (i.e., rainfall and critical depth) $\left[\mathrm{T}^{-1}\right], q_{\mathrm{sp}}^{\mathrm{e}}$ is the rate of water exchange between the subsurface and surface continua $\left[\mathrm{T}^{-1}\right]$, and $h_{\mathrm{s}}$ is the average height of non-discretized surface microtopography [L], $t$ is the time [T]. $S_{\mathrm{w}_{\mathrm{s}}}[-]$ is the surface saturation, and defined as

$$
S_{\mathrm{w}_{\mathrm{s}}}=\psi_{\mathrm{r}}^{2\left(1-\psi_{\mathrm{r}}\right)},
$$

where $\psi_{\mathrm{r}}[-]$ is the surface water depth relative to $h_{\mathrm{s}}$, represented by

$$
\psi_{\mathrm{r}}=\min \left[1, \max \left[0, \psi_{\mathrm{s}} / h_{\mathrm{s}}\right]\right] .
$$

$\psi_{\mathrm{s}}^{\text {mobile }}[\mathrm{L}]$ and $\psi_{\mathrm{s}}^{\text {store }}[\mathrm{L}]$ are the mobile and stored water depths, respectively, and are defined as

$$
\left\{\begin{array}{l}
\psi_{\mathrm{s}}^{\text {mobile }}=\max \left[0, \psi_{\mathrm{s}}-\psi_{\mathrm{s}}^{\mathrm{pond}}\right] \\
\psi_{\mathrm{s}}^{\text {store }}=\max \left[0, \psi_{\mathrm{s}}-h_{\mathrm{s}}\right]
\end{array}\right.
$$

where $\psi_{\mathrm{s}}^{\text {pond }}[\mathrm{L}]$ is the depth of ponded water that does not participate in overland flow (e.g., depression storage).

3D subsurface flow in variably saturated porous medium is estimated in InHM by

$$
\nabla \cdot f^{\mathrm{a}} \boldsymbol{q} \pm q^{\mathrm{b}} \pm q_{\mathrm{ps}}^{\mathrm{e}}=f^{\mathrm{v}} \frac{\partial \varphi S_{\mathrm{w}}}{\partial t}
$$

where $q_{\mathrm{ps}}^{\mathrm{e}}$ (equals $\left.-q_{\mathrm{sp}}^{\mathrm{e}}\right)\left[\mathrm{T}^{-1}\right]$ is the surfacesubsurface water exchange rate, $\varphi[-]$ is the porosity, 
$S_{\mathrm{w}}[-]$ is the water saturation, $f^{\mathrm{a}}[-]$ is the area fraction associated with each continuum, and $f^{v}$ is the volume fraction associated with each continuum. $\boldsymbol{q}\left[\mathrm{LT}^{-1}\right]$ is the Darcy flux, and is given by

$$
\boldsymbol{q}=-k_{\mathrm{rw}} \frac{\rho_{\mathrm{w}} g}{\mu_{\mathrm{w}}} \boldsymbol{k} \nabla(\psi+z)
$$

where $k_{\mathrm{rw}}[-]$ is the relative permeability, $\rho_{\mathrm{w}}\left[\mathrm{ML}^{-3}\right]$ is the density of water, $g\left[\mathrm{LT}^{-2}\right]$ is the gravitational acceleration, $\mu_{\mathrm{w}}\left[\mathrm{ML}^{-1} \mathrm{~T}^{-1}\right]$ is the viscosity of water, $\boldsymbol{k}$ $\left[\mathrm{L}^{2}\right]$ is the intrinsic permeability vector, $z[\mathrm{~L}]$ is the elevation head, and $\psi[\mathrm{L}]$ is the pressure head.

The governing Eqs. (1) and (5) are discretized in space using the control volume finite-element method. Each coupled system of nonlinear equations in an InHM simulation is solved implicitly using the Newton iteration.

\subsection{Sensitivity analysis}

The input settings in InHM contain initial conditions (i.e., initial soil water content), boundary conditions (i.e., the outlet and rainfall), and surface and soil properties. The seven parameters considered in the sensitivity analysis are (1) the rainfall rate, $R$, (2) the initial soil water content, $S$, (3) the Manning's roughness coefficient, $n,(4)$ the saturated hydraulic conductivity, $K_{\mathrm{S}}$, (5) the soil porosity, $p$, and the two parameters of the soil water retention curve (6) $\alpha$ and (7) $\beta$. The sensitivity of the InHM simulated hydrologic response is investigated by individually increasing/decreasing (i.e., relatively plus/minus $20 \%$ changes) the values of the seven parameters and conducting 14 simulations. The base case parameter values and the results from the 14 simulations as percentage differences of the peak flow relative to the base-case simulation are presented in Table 1 .

It can be seen that the seven parameters all result in changes in the simulated water discharge, particularly the initial soil water content and the Beta parameter of the soil water retention curve (i.e., the $20 \%$ decrease in $S$ and $\beta$ lead to $91.9 \%$ and $61.5 \%$ lower peak flow, respectively).

In this study, the parameters used in the calibration are partly obtained by measuring, and the others are judged by the reasonable range or are calibrated.
The details will be described in the following paragraphs.

Table 1 Sensitivity analysis results for InHM simulations of hydrologic response



* Percentage differences (relative to the base case) in simulated peak flow for increased/decreased parameter values

\subsection{Settings in simulation}

The 2D surface mesh for the Jianpinggou catchment is shown in Fig. 2, and the 3D mesh was constructed by adding layers. The 2D surface mesh was formed based on the DEM with a resolution of $5 \mathrm{~m}$ surveyed before the earthquake. Taking into account the impact of landslides on the local topography, the mesh was different after the earthquake. The DEM after the earthquake (in 2011) with a resolution of $30 \mathrm{~m}$ was used to modify the elevation rather than simulate the hydrologic response, to reduce the error of hydrological simulation caused by the resolution of DEM (Zhang and Montgomery, 1994; Sulis et al., 2011). The remote sensing image was also used for the modification. The difference between the two meshes is the elevation of the landslide area, which is shown in Fig. 2b. In both meshes, the horizontal nodal spacing along the channel was $10 \mathrm{~m}$, and on the boundary was $100 \mathrm{~m}$. The vertical profile has three layers with the nodal spacing of $0.1 \mathrm{~m}, 0.5 \mathrm{~m}$, and $1 \mathrm{~m}$. The number of the nodes and elements in the mesh totaled 244160 and 129192 , respectively.

According to the soil profile of the Jianpinggou catchment, the soil properties of the three soil layers were identified. The first soil horizon was $0.5 \mathrm{~m}$ thick, and heterogeneous. The soil properties (e.g., porosity and saturated permeability coefficient) were measured at three locations in November 2011. The 




(a)

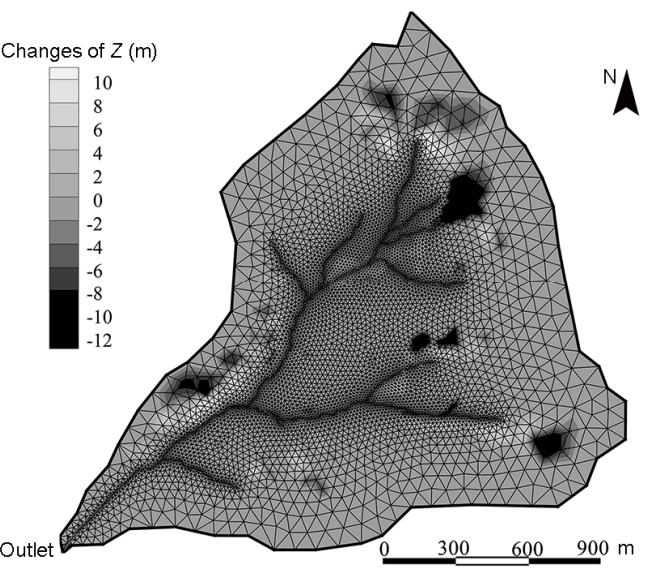

(b)

Fig. 2 Finite-element meshes for the Jianpinggou catchment

(a) Soil measurement and data collection; (b) Changes of elevation induced by landslides

locations were not spotted in the upstream area due to the lush vegetation and steep hill slopes (Fig. 2a). According to the impact of the landslide on the topography, the soil properties of the elevation-reduced area were assumed the same as the properties of the bedrock, and in the elevation-increased area, the soil was more permeable. The second soil horizon was $2.5 \mathrm{~m}$ thick with a high content of bedrock fragments, and the underlying bedrock was $10 \mathrm{~m}$ thick. Both horizons were assumed to be homogeneous and isotropic. The main soil properties set in InHM are listed in Table 2. The soil water retention curve was estimated via the van Genuchten method (van Genuchten, 1980), and the parameters ( $\alpha$ and $\beta$ ) in the method are obtained by calibration. The Manning's roughness in the surface was calculated by (Gabet and Dunne, 2003)

$$
n=0.053 \mathrm{e}^{2.7 C_{\mathrm{v}}},
$$

where $C_{\mathrm{v}}$ is the vegetation coverage, and expressed as a decimal. The vegetation coverage in the Jianpinggou catchment decreased from about $95 \%$ to $75 \%$ due to the earthquake (Ni et al., 2009). Therefore, the Manning's roughness was calculated by Eq. (7), and was set to 0.69 for the condition of before-earthquake period, and 0.4 for the afterearthquake period.

The initial soil water contents of the validation period were set through a warm-up simulation, which
Table 2 Main soil properties set in InHM

\begin{tabular}{|c|c|c|c|c|}
\hline \multicolumn{2}{|c|}{ Item } & $K_{\mathrm{S}}(\mathrm{m} / \mathrm{s})$ & $p$ & Note \\
\hline \multirow{3}{*}{$\begin{array}{c}\text { Surface } \\
\text { soil }\end{array}$} & L1 & $1.29 \times 10^{-4}$ & 0.756 & \multirow{3}{*}{ By measurement } \\
\hline & L2 & $4.63 \times 10^{-5}$ & 0.723 & \\
\hline & L3 & $1.24 \times 10^{-5}$ & 0.650 & \\
\hline \multicolumn{2}{|c|}{$\begin{array}{l}\text { Elevation- } \\
\text { reduced area }\end{array}$} & $1 \times 10^{-8}$ & 0.4 & $\begin{array}{l}\text { The same as the } \\
\text { bedrock }\end{array}$ \\
\hline \multicolumn{2}{|c|}{$\begin{array}{l}\text { Elevation- } \\
\text { increased area }\end{array}$} & $1 \times 10^{-4}$ & 0.7 & $\begin{array}{l}\text { Assumed based } \\
\text { on the mean } \\
\text { observed values }\end{array}$ \\
\hline \multicolumn{2}{|c|}{$\begin{array}{l}\text { The second } \\
\text { soil horizon }\end{array}$} & $1 \times 10^{-3}$ & 0.7 & $\begin{array}{l}\text { Assumed based on } \\
\text { the gravel permea- } \\
\text { bility and mean } \\
\text { observed porosity }\end{array}$ \\
\hline \multicolumn{2}{|c|}{ Bedrock } & $1 \times 10^{-8}$ & 0.4 & $\begin{array}{l}\text { Assumed within } \\
\text { reasonable range }\end{array}$ \\
\hline
\end{tabular}

results in the non-uniform distribution of the soil water contents and the similar discharge to the measured discharge at the outlet of the catchment just prior to the validation period.

Because the hydrological data was collected after the earthquake, there are no hydrological measurements before 2008. The condition of the afterearthquake period was then used for the model calibration. The study period is from 16th September to 14th October, 2011. The first 15 d' (16th to 30th September) data was used for calibration, and the remaining $14 \mathrm{~d}$ ' data was used for validation.

Three main simulation scenarios (Table 3 ) are set to analyze the impact of landslides on the hydrologic 
response, and the variation of the impact with increasing rainfall. Both conditions of before and after the earthquake are contained in each scenario.

Table 3 Three main simulation scenarios in the study

\begin{tabular}{|c|c|c|c|c|}
\hline $\begin{array}{l}\text { Sce- } \\
\text { nario }\end{array}$ & $\begin{array}{l}\text { Initial soil } \\
\text { water } \\
\text { content }\end{array}$ & Rainfall & $\begin{array}{l}\text { Simulat- } \\
\text { ed time } \\
\text { (d) }\end{array}$ & Note \\
\hline 1 & $\begin{array}{c}\text { About } \\
80 \% \text { of } \\
\text { saturation }\end{array}$ & Observed & 29 & $\begin{array}{l}\text { Maximum rainfall } \\
\text { intensity is } \\
1.25 \times 10^{-6} \mathrm{~m} / \mathrm{s} \\
\text { total rainfall is } \\
104.7 \mathrm{~mm}\end{array}$ \\
\hline 2 & $\begin{array}{c}\text { About } \\
20 \% \text { of } \\
\text { saturation }\end{array}$ & Observed & 29 & $\begin{array}{l}\text { To reduce the } \\
\text { influence of the } \\
\text { subsurface flow }\end{array}$ \\
\hline 3 & $\begin{array}{c}\text { About } \\
20 \% \text { of } \\
\text { saturation }\end{array}$ & $\begin{array}{c}\text { Estimated } \\
\text { increasing } \\
\text { rainfall }\end{array}$ & 1 & $\begin{array}{l}\text { Rainfall duration } \\
\text { is } 6 \mathrm{~h} \text {; five differ- } \\
\text { ent frequencies; to } \\
\text { analyze the varia- } \\
\text { tion of the impact }\end{array}$ \\
\hline
\end{tabular}

\section{Results and discussion}

InHM was employed to simulate the hydrologic response in the Jianpinggou catchment for the calibration and validation periods. The hydrograph at the outlet of the catchment is shown in Fig. 3 as well as the measured hydrograph and rainfall information.

Fig. 3 shows that the simulated integrated response (discharge) fits well with the observed values in both periods. But the error in the rising limb cannot be ignored, which may be caused by the unrealistic initial conditions, since the initial soil water content was set by only the closed discharge value but not the measured distributed soil water content. The NashSutcliffe efficiency coefficient (NSE) is used for the accuracy assessment of the simulation, which is calculated as (Nash and Sutcliffe, 1970)

$$
\mathrm{NSE}=1-\frac{\sum_{i=1}^{N}\left[q_{0}(i)-q_{\mathrm{s}}(i)\right]^{2}}{\sum_{i=1}^{N}\left[q_{0}(i)-\bar{q}_{0}\right]^{2}},
$$

where $q_{0}(i)$ is the observed discharge; $q_{\mathrm{s}}(i)$ is the simulated discharge; $N$ is the number of samples; and $\bar{q}_{0}$ is the mean of the observed discharge. The NSE ranges from $-\infty$ to 1 , with 1 indicating a perfect match between the observed and simulated values. In this study, the NSE is 0.790 for calibration and 0.877 for validation, which reveals that this simulation can be accepted as a true representation of the actual hydrologic response.

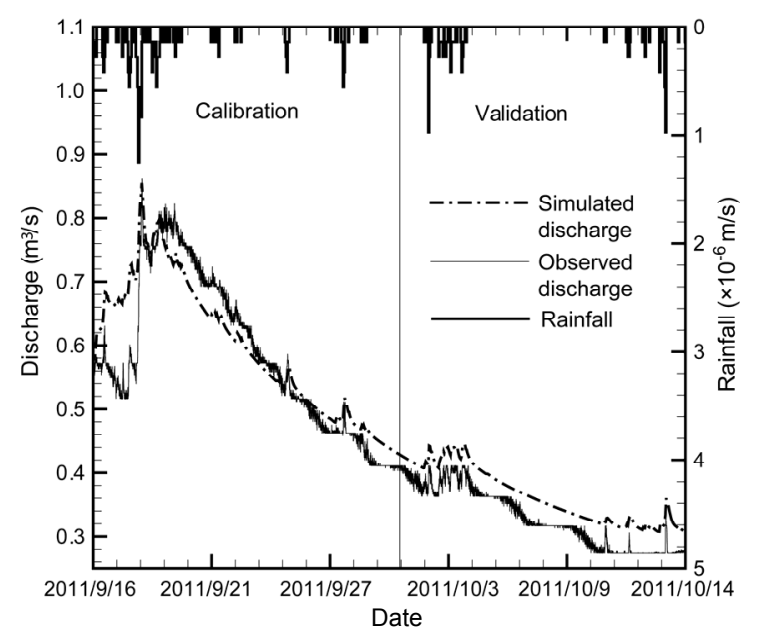

Fig. 3 Observed versus InHM-simulated discharges

It can be seen from the observed hydrograph (Fig. 3) that, the discharge does not correspond exactly with the rainfall in this study period. Actually, the hydrograph seems to be a part of the recession process of a previous flood event. This phenomenon is mainly due to the special runoff generation mechanisms, the Dunne overland flow, and the large proportion of subsurface flow, in the Jianpinggou catchment. However, note that the purpose of this study is focused on the impact of earthquakeinduced-landslides on the hydrologic response, but not flood events.

The condition of the before-earthquake period (S1b) was simulated based on the same inputs. Comparisons of the hydrograph at the outlet between the conditions of before (S1b) and after (S1a) earthquakes are shown in Fig. 4. It shows that no significant differences exist between the two conditions. The impact of landslides on the hydrologic response mainly focuses on the surface flow due to the changes of the topography and surface infiltration. However, the subsurface flow from the previous rainfall event occupies a large proportion of the hydrologic 
response due to the high water content (about $80 \%$ of saturation) in the study period (at the end of the wet season). Thus, the impact of landslides is masked by the initial conditions in this simulation.

Based on the applicability of InHM in the Jianpinggou catchment, a different initial condition of much lower water content (about $20 \%$ of saturation) was applied to highlight the influence of landslides. The following studies were all based on the initial conditions of the lower water content.

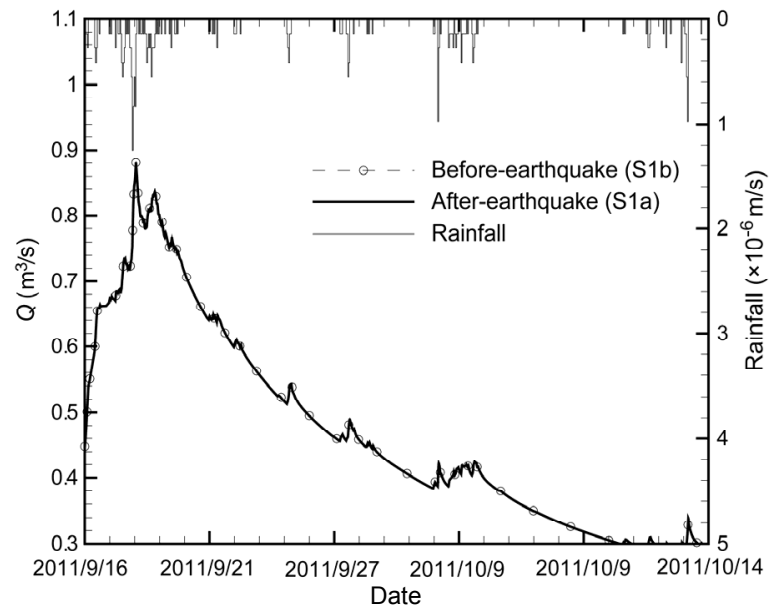

Fig. 4 Simulated discharge $(Q)$ before and after earthquakes in Scenario 1

\subsection{Settings in simulation}

\subsubsection{Integrated hydrologic response}

Fig. 5 is the hydrograph of before- and afterearthquake states under the new initial condition (Scenario 2). It is evident that the shape of the hydrograph has insignificant differences, but the initialrunoff-time appears earlier by about $10 \%$ after the earthquake, and the peak is also increased slightly after the earthquake, which is estimated to be about $1.7 \%$. The increased discharge mainly results from the increased surface flow in the landslide-affected region. However, the affected area is only a small proportion of the total catchment. The surface flow is just a part of the total runoff, sometimes even less than the subsurface flow. Therefore, although the impact of landslides on the hydrological response in the Jianpinggou catchment existed, this is not so obvious due to the characteristics of the runoff generation mechanism.

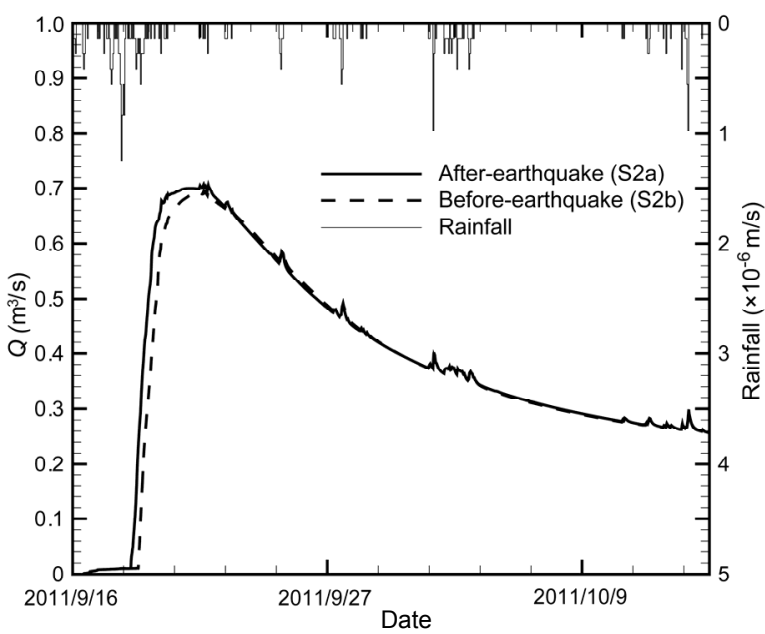

Fig. 5 Simulated discharge $(Q)$ before and after earthquake in Scenario 2

\subsubsection{Spatially distributed hydrologic response}

Figs. 6 and 7 are the flow depth and hydrographs at the outlet of the two main tributaries in the Jianpinggou catchment. It shows that the flow depths at the specific points are both enhanced by about $0.1 \mathrm{~m}$ after the landslides occurred. Compared with the whole catchment, the peak discharges of both tributaries have increased more after the landslides occurred, with about $12 \%$ growth in the southern tributary. The possible reason for the greater growth in the tributaries may be due to the smaller distance from the landslides to the outlet, and the formation of a larger proportion of the landslide-affected area.

The spatial distribution of the impact is represented not only by the discharge and flow depth of the observation points, but also by the distributions of the saturation and surface flow depth (Figs. 8 and 9). It is apparent that the spatial distribution of these two parameters has significant differences between beforeand after-earthquake conditions (S2b and S2a). It follows that the landslides induced by the earthquake have a non-negligible impact on the runoff generation and convergence process, especially in the region of the runoff generation.

Based on the spatial distribution of the discharge, saturation, and flow depth, it can be inferred that the impact of the landslides on the hydrologic response is not uniform in the space over the catchment. The changes of the hydrologic response are 

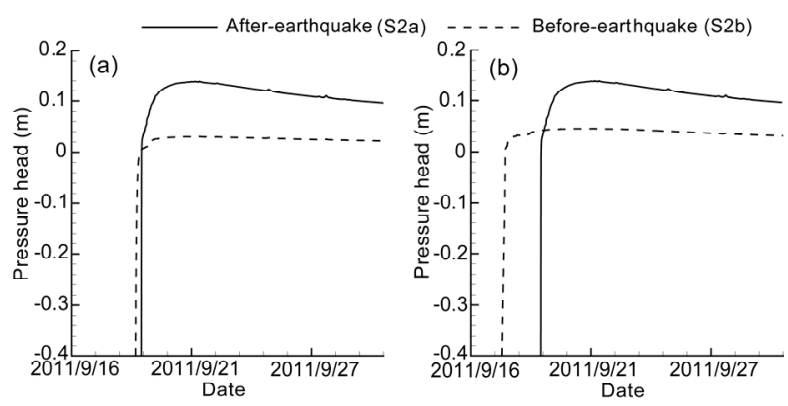

Fig. 6 Pressure head at the points near the outlet of the southern tributary (a) and northern tributary (b)

The value of the pressure head reaching 0 means the saturation, and greater than 0 indicates the value of the surface flow depth
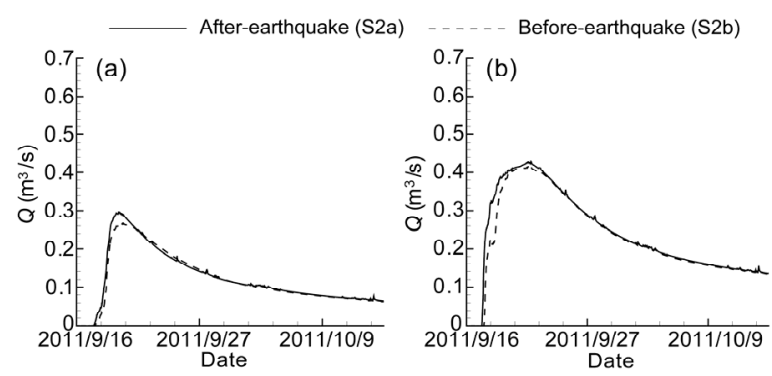

Fig. 7 Simulated discharge $(Q)$ at the outlet of the southern tributary (a) and northern tributary (b)



Fig. 8 Saturation distribution $(S)$ at the peak moment (a) After-earthquake; (b) Before-earthquake

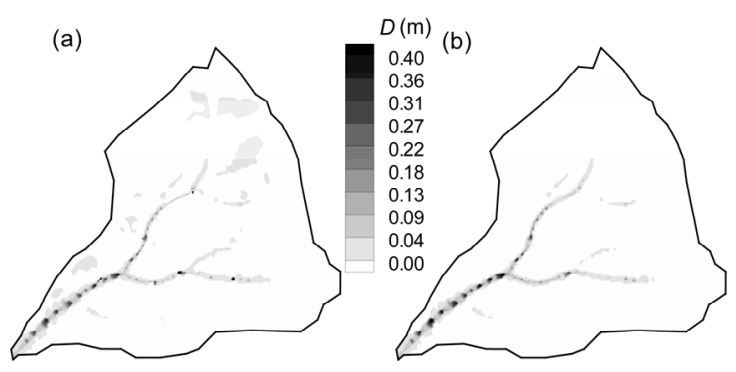

Fig. 9 Flow depth $(D)$ distribution at the peak moment (a) After-earthquake; (b) Before-earthquake insignificant at the catchment scale, but cannot be ignored at some specific locations. The visible growth of the flow depth and peak discharge in some local areas may elevate the local flash flood risks and increase the disaster losses.

\subsection{Variation of the impact with increasing rainfall}

As mentioned above, the impact of the landslides induced by the earthquake on the integrated hydrologic response in the Jianpinggou catchment existed, but not remarkably, especially in the conditions of the small proportion of the surface flow in the total runoff. The new conditions of increasing rainfall (Scenario 3) were set to confirm the variations of the impact (represented as IP/PB, increase of the peak divided by the peak of the before-earthquake condition). Based on the Estimate Manual of the Stormflood in Medium and Small Watersheds, Sichuan (SPWRPD, 1984), the rainfalls of 6-h in duration and with different rainfall intensity were estimated (Fig. 10 and Table 4). Then the hydrologic responses of before- and after-earthquake conditions were simulated (Scenario 3), and the IP/PB ratios under different rainfalls were calculated.

The five rainfall events all have the relative high intensity and large total rainfall, but the runoff is much smaller than expected. Here, the runoff of the R5 event is used as an example for analysis (Fig. 11). In the simulation of the R5 event, the duration of rainfall is $6 \mathrm{~h}$, and the simulated time is $3 \mathrm{~d}(259200 \mathrm{~s})$. It can be seen that the hydrologic response during the R5 event is very complex. It has two peaks: one responded rapidly to the rainfall, but the value is relatively low; the other occurred much later, more than $2 \mathrm{~d}$ after the end of the rainfall, but the value is larger than the first peak. The reason of this complex hydrologic response may be attributed to the special runoff generation mechanisms in the Jianpinggou catchment. The rainfall intensity of the five rainfall events in Scenario 3 are all smaller than the saturated hydraulic conductivity $K_{\mathrm{S}}$ of most areas, so the runoffs are still dominated by the Dunne overland flow and subsurface flow, and the runoff generation locations usually just distribute in the channel and adjacent areas due to the convergence and the 
non-uniform distribution of the soil saturation. Therefore, with the very low initial soil water content (with a saturation of only $20 \%$ ), only a part of the rainfall in Scenario 3 will become direct runoff, and most of the rainfall will be infiltrated, and then converge to the outlet by subsurface flow in a later period. Thus, the two peaks occurred.



Fig. 10 Estimated rainfalls with 6-h duration and different intensities

Table 4 Increased rainfall characteristics

\begin{tabular}{lcc}
\hline Rainfall & $\begin{array}{c}\text { Maximum rainfall } \\
\text { intensity }(\mathrm{m} / \mathrm{s})\end{array}$ & $\begin{array}{c}\text { Total rainfall } \\
(\mathrm{mm})\end{array}$ \\
\hline R1 & $1.57 \times 10^{-5}$ & 164 \\
R2 & $1.86 \times 10^{-5}$ & 195 \\
R3 & $2.25 \times 10^{-5}$ & 235 \\
R4 & $2.53 \times 10^{-5}$ & 265 \\
R5 & $2.81 \times 10^{-5}$ & 294 \\
\hline
\end{tabular}



Fig. 11 Discharge and rainfall of the $\mathbf{R 5}$ event in Scenario 3
Compared Scenario 1 with Scenario 2, the impact of landslides induced by the earthquake is proportional to the proportion of the surface flow in the total runoff. Considering the characteristics of the discharge of the five rainfall events in Scenario 3, the second peak basically relies on the subsurface flow, and surface flow only influences the first peak. So the first peak of the five events in Scenario 3 is used to study the variation of the landslide impact, due to the very small proportion of the subsurface flow.

The first peaks of different rainfalls in Scenario 3 are shown in Fig. 12. It indicates that the increase of the first peak flow induced by the landslides is more significant with a heavier rainfall. For example, the difference of the first peak flow between the beforeand after-earthquake conditions under the R5 event is much larger (about four times) than that under the R4 event. A threshold can be assumed at the R3 event (with the total rainfall of $235 \mathrm{~mm}$ ), due to the rapid growth of the first peak flow under the R4 and R5 events.

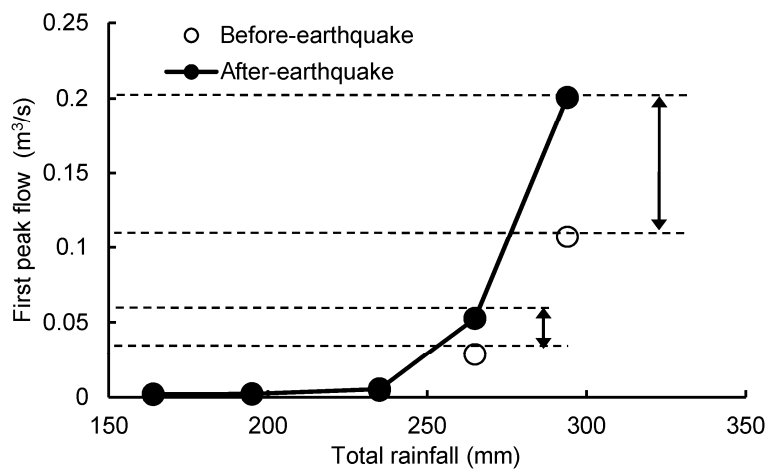

Fig. 12 The first peak flow of five different rainfall events R1-R5 in Scenario 3

Fig. 13 illustrates the IP/PB ratios of the five different rainfall events. It is apparent that the IP/PB ratios are very small for the $\mathrm{R} 1$ and $\mathrm{R} 2$ events, and increase to about $15 \%$ for the R3 event, then rapidly rise to about $85 \%$ for the $\mathrm{R} 4$ event. Then the growth becomes very gentle, and the value of the IP/PB ratio only increases up to about $87 \%$ when the total rainfall has reached $294 \mathrm{~mm}$ in $6 \mathrm{~h}$ (R5 event). It can be summed up that the IP/PB ratio is enhanced with the increasing rainfall (a threshold for rapid growth also at the total rainfall of $235 \mathrm{~mm}$ ), but there is a limit to the further enlarged rainfall. 


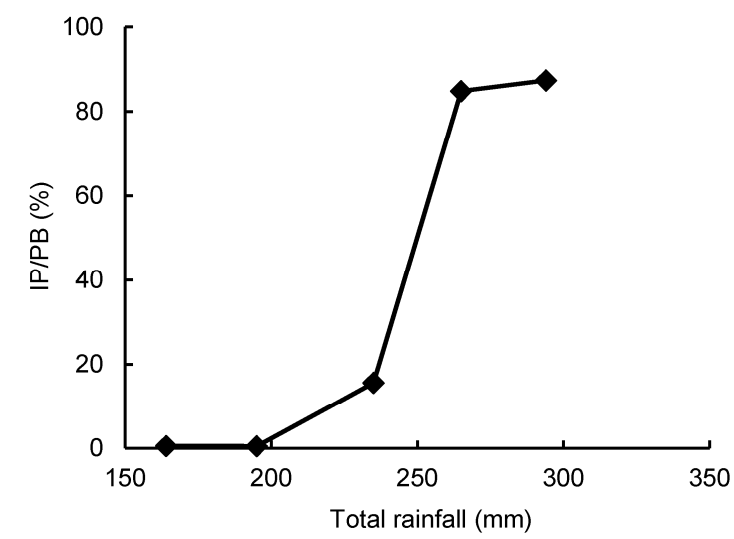

Fig. 13 IP/PB ratios of the five different rainfall events R1-R5 in Scenario 3

In the five cases of increasing rainfall, the maximum rainfall intensity is still lower than the saturated hydraulic conductivity $K_{\mathrm{S}}$ of the surface soil (in addition to the elevation-reduced area). So the Dunne overland flow and subsurface flow are still the dominant runoff generation mechanism in this catchment. It should be recognized that this part of the runoff is relatively small, due to the short rainfall duration $(6 \mathrm{~h})$, the short simulated period, as well as the low initial saturation. On the other hand, the Horton overland flow may generate in the elevationreduced area, because of the much lower $K_{\mathrm{S}}$. The Horton flow will be directly related to the rainfall, but a certain distance of the convergence will change part or all of the flow to infiltration. Therefore, the Horton flow may influence the runoff at the outlet just under the large rainfall conditions, which may lead to the existence of the threshold of the R3 event. With increasing rainfall, the overland flow is increased, but the infiltration has a limit, so the calculated IP/PB ratio will reach the limit.

\section{Conclusions}

The evident changes of the underlying surface conditions (topography and vegetation cover rate) in the Jianpinggou catchment were caused by the numerous landslides in the Wenchuan earthquake. The impact of the landslides on the hydrologic response in the catchment was investigated, and the results are summarized as follows.
1. The impact of earthquake-induced-landslides on the hydrologic response does exist. The peak flow has increased after the landslide occurred. The greater the proportion of the surface flow in the total runoff, the more visible the impact.

2. The effect of landslides on the runoff is not very obvious at the outlet, and the shape of the hydrograph has little change; however, it should not be ignored at the local positions, which suggests that the local flash flood risks are elevated after the earthquake.

3. The impact on the peak flow will be more obvious with increasing rainfall. In the study area, when the dominant runoff is surface flow, the difference of the first peak flow between the before- and after-earthquake conditions under the R5 event is much larger (about four times) than that under the R4 event.

4. The impact of landslides will increase rapidly at a threshold of the runoff (the total rainfall of $235 \mathrm{~mm}$ in $6 \mathrm{~h}$ in the study area), but there is a limit with the further enlarged rainfall. This threshold for the rapid growth provides valuable theoretical support for the storm flood forecast after the earthquake.

\section{References}

Bari, M.A., Smettem, K.R.J., Sivapalan, M., 2005. Understanding changes in annual runoff following land use changes: a systematic data-based approach. Hydrological Processes, 19(13):2463-2479. [doi:10.1002/hyp.5679]

BeVille, S.H., Mirus, B.B., Ebel, B.A., et al., 2010. Using simulated hydrologic response to revisit the 1973 Lerida Court landslide. Environmental Earth Sciences, 61(6): 1249-1257. [doi:10.1007/s12665-010-0448-z]

Campana, N.A., Tucol, C.E.M., 2001. Predicting floods from urban development scenarios: case study of the Diiuvio Basin, Porto Alegre, Brazil. Urban Water, 3(1-2):113124. [doi:10.1016/S1462-0758(01)00004-8]

Chen, J.C., 2011. Variability of impact of earthquake on debrisflow triggering conditions: case study of Chen-Yu-Lan watershed, Taiwan. Environmental Earth Sciences, 64(7): 1787-1794. [doi:10.1007/s12665-011-0981-4]

Chu, S.M., Yu, B., Li, L., et al., 2011. Forming mechanism and characteristics of debris flow happened on August 13, 2010 in Jianping Gully. Soil and Water Conservation in China, 8:52-54 (in Chinese).

Cui, P., Zhuang, J.Q., Chen, X.C., et al., 2010. Characteristics and countermeasures of debris flow in Wenchuan area after the earthquake. Journal of Sichuan University (Engineering Science Edition), 42:10-19 (in Chinese).

Cui, P., He, S.M., Yao, L.K., et al., 2011. Formation Mechanisms and Risk Assessment of Geological Hazards Trig- 
gered by the Wenchuan Earthquake. Science Press, Beijing (in Chinese).

Dunne, T., Zhang, W.H., Aubry, B.F., 1991. Effects of rainfall, vegetation, and microtopography on infiltration and runoff. Water Resources Research, 27(9):2271-2285. [doi:10. 1029/91WR01585]

Ebel, B.A., Loague, K., Montgomery, D.R., et al., 2008. Physics-based continuous simulation of long-term near-surface hydrologic response for the Coos Bay experimental catchment. Water Resources Research, 44(7): W07417. [doi:10.1029/2007WR006442]

Ebel, B.A., Loague, K., Borja, R.I., 2010. The impacts of hysteresis on variably saturated hydrologic response and slope failure. Environmental Earth Sciences, 61(6):12151225. [doi:10.1007/s12665-009-0445-2]

Gabet, E.J., Dunne, T., 2003. Sediment detachment by rain power. Water Resources Research, 39(1):ESG 1-1-ESG 1-12. [doi:10.1029/2001WR000656]

Heppner, C.S., Loague, K., 2008. Characterizing long-term hydrologic-response and sediment-transport for the R-5 catchment. Journal of Environmental Quality, 37(6): 2181-2191. [doi:10.2134/jeq2007.0548]

Heppner, C.S., Ran, Q.H., VanderKwaak, J.E., et al., 2006. Adding sediment transport to the integrated hydrology model (InHM): development and testing. Advances in Water Resources, 29(6):930-943. [doi:10.1016/j.advwatres. 2005.08.003]

Hong, N.M., Chu, H.J., Lin, Y.P., et al., 2010. Effects of land cover changes induced by large physical disturbances on hydrological responses in Central Taiwan. Environmental Monitoring and Assessment, 166(1-4):503-520. [doi:10. 1007/s10661-009-1019-1]

Liu, Q.Q., Singh, V. P., 2004. Effect of microtopography, slope length and gradient, and vegetative cover on overland flow through simulation. Journal of Hydrologic Engineering, 9(5):375-382. [doi:10.1061/(ASCE)1084-0699 (2004)9:5(375)]

Liu, S.G., Wang, Z.Y., Gong, Z., et al., 2006. Physically based modeling and animation of tornado. Journal of Zhejiang University-SCIENCE A, 7(7):1099-1106. [doi:10.1631/ jzus.2006.A1099]

Loague, K., VanderKwaak, J.E., 2002. Simulating hydrological response for the R-5 catchment: comparison of two models and the impact of the roads. Hydrological Processes, 16(5):1015-1032. [doi:10.1002/hyp.316]

Loague, K., Heppner, C.S., Abrams, R.H., et al., 2005. Further testing of the integrated hydrology model (InHM): event-based simulations for a small rangeland catchment located near Chickasha, Oklahoma. Hydrological Processes, 19(7):1373-1398. [doi:10.1002/hyp.5566]

Mirus, B.B., Loague, K., 2013. How runoff begins (and ends): characterizing hydrologic response at the catchment scale. Water Resources Research, 49(5):2987-3006. [doi:10.1002/wrcr.20218]

Mirus, B.B., Loague, K., VanderKwaak, J.E., et al., 2009. A hypothetical reality of Tarrawarra-like hydrologic response. Hydrological Processes, 23(7):1093-1103. [doi:10.1002/hyp.7241]

Mirus, B.B., Ebel, B.A., Heppner, C.S., et al., 2011. Assessing the detail needed to capture rainfall-runoff dynamics with physics-based hydrologic response simulation. Water Resources Research, 47(3):W00H10. [doi:10.1029/ 2010WR009906]

Nash, J.E., Sutcliffe, J.V., 1970. River flow forecasting through conceptual models, part I-a discussion of principles. Journal of Hydrology, 10(3):282-290. [doi:10.1016/ 0022-1694(70)90255-6]

Ni, Z.Y., He, Z.W., Zhao, Y.B., et al., 2009. Study on vegetation coverage changes in Dujiangyan before and after Wenchuan earthquake. Research of Soil and Water Conservation, 16:45-48 (in Chinese).

Qian, Q., Ran, Q.H., 2012. Numerical simulation of rainfallrunoff in Longmen mountain watershed. Journal of Hydraulic Engineering, 43(S2):88-93 (in Chinese).

Ran, Q.H., Heppner, C.S., VanderKwaak, J.E., et al., 2007. Further testing of the integrated hydrology model (InHM): multiple-species sediment transport. Hydrological Processes, 21(11):1522-1531. [doi:10.1002/hyp. 6642]

Ran, Q.H., Loague, K., VanderKwaak, J.E., 2012. Hydrologicresponse-driven sediment transport at a regional scale, process-based simulation. Hydrological Processes, 26(2): 159-167. [doi:10.1002/hyp.8122]

Ran, Q.H., Shi, Z.N., Xu, Y.P., 2013. Canonical correlation analysis of hydrological response and soil erosion under moving rainfall. Journal of Zhejiang UniversitySCIENCE A (Applied Physics \& Engineering), 14(5): 353-361. [doi:10.1631/jzus.A1200306]

Shi, M.J., Chen, K., 2004. Land degradation, government subsidy, and smallholders' conservation decision: the case of the loess plateau in China. Journal of Zhejiang University-SCIENCE, 5(12):1533-1542. [doi:10.1631/ jzus.2004.1533]

SPWRPD (Sichuan Provincial Water Resources and Power Department), 1984. Estimation Manual of the Stormflood in Medium and Small Watersheds, Sichuan. Sichuan Provincial Water Resources and Power Department, Chengdu, China, p.2-8 (in Chinese).

Sulis, M., Paniconi, C., Camporese, M., 2011. Impact of grid resolution on the integrated and distributed response of a coupled surface-subsurface hydrological model for the Des Anglais catchment, Quebec. Hydrological Processes, 25(12):1853-1865. [doi:10.1002/hyp.7941]

VanderKwaak, J.E., 1999. Numerical Simulation of Flow and Chemical Transport in Integrated Surface-subsurface Hydrologic Systems. PhD Thesis, University of Waterloo, Waterloo.

VanderKwaak, J.E., Loague, K., 2001. Hydrologic-response simulations for the R-5 catchment with a comprehensive physics-based model. Water Resources Research, 37(4): 999-1013. [doi:10.1029/2000WR900272]

van Genuchten, M.T., 1980. A closed-form equation for predicting the hydraulic conductivity of unsaturated soils. Soil Science Society of America Journal, 44(5):892-898. 
[doi:10.2136/sssaj1980.03615995004400050002x]

Xu, M.Z., Wang, Z.Y., Shi, W.J., et al., 2010. Mountain disaster chain induced by the Wenchuan earthquake in the Huoshiguo Gorge. Journal of Tsinghua University (Science and Technology), 50(9):1338-1341 (in Chinese).

Zhang, W.H., Montgomery, D.R., 1994. Digital elevation model grid size, landscape representation, and hydrologic simulations. Water Resources Research, 30(4):10191028. [doi:10.1029/93WR03553]

Zheng, S.W., Mu, C.L., Chen, Z.M., et al., 2010. Simulations and analysis on the effects of forest on the hydrological processes in the upper reaches of Yangtze River. Acta Ecologica Sinica, 30(11):3046-3056 (in Chinese).

\section{中文概要}

\section{题 目: 震后滑坡对陡峭山区小流域水文响应过程的影响 - - 以汶川地震影响区小流域为例}

目 的：明确汶川地震所引发的滑坡对震区小流域水文响 应过程的影响, 推进震区洪水过程的准确预报。
创 新：评估汶川地震对碱坪沟流域的下垫面条件的破 坏, 并在此基础上利用先进的分布式水文模型定 量评估地震事件对小流域产汇流过程的影响。

方 法：1. 选取四川省龙溪河地区的碱坪沟小流域作为研 究区域, 利用遥感影像数据以及数字高程数据获 得滑坡区的分布以及高程变化情况; 2. 运用基于 物理概念的综合水文模型 (InHM) 对该流域水文 过程进行模拟精度验证; 3. 对滑坡发生前后的降 雨产流过程分别进行数值模拟, 探讨在同样降雨 条件下, 由于滑坡所引起的下垫面特性变化对产 流过程的影响。

结 论: 1. 震后滑坡灾害所带来的下垫面变化导致了流域 内的山洪特性变化, 且在流域内局部地区的表现 更为明显, 局部山洪危害增加; 2. 与震前相比, 随着暴雨规模的增强, 震后下垫面变化所致的流 量峰值增量也随之增加, 峰值的增加比例在 6 小 时雨量达到 $235 \mathrm{~mm}$ 时急剧增大, 但降雨持续增 强后趋近于稳定值（约 $87 \%$ ）。

关键词: 水文响应; 数值模拟; 下垫面条件; 地震; 滑坡 